\title{
ULOGA INFORMIRANOSTI U POZNAVANJU PROBLEMATIKE OPĆEKORISNIH FUNKCIJA ŠUMA
}

\section{THE ROLE OF INFORMATION IN UNDERSTANDING FOREST ECOSYSTEM SERVICES}

\author{
Silvija Krajter OSTOIĆ ${ }^{1}$ Dijana VULETIĆ
}

\begin{abstract}
Sažetak
Općekorisne funkcije šuma važna su znanstvena i stručna tema o kojoj se na globalnoj razini raspravlja već dugi niz godina. U Hrvatskoj također postoje višegodišnji napori u promišljanju sistematizacije i vrednovanja općekorisnih funkcija šuma, kao i osiguravanju naknade za njihovo pružanje. Ipak, pregled literature pokazuje da opseg znanstvene i stručne produkcije nije u skladu s važnosti ove teme za hrvatsko šumarstvo. Posebice se to odnosi na istraživanje stavova i percepcije građana, kao i njihove informiranosti o problematici općekorisnih funkcija šuma. Cilj je ovog članka analizirati ulogu informiranosti na poznavanje problematike općekorisnih funkcija šuma, uz pretpostavku da veća informiranost vodi i boljem poznavanju te problematike. Korištena je metoda ankete na uzorku populacije studenata triju raznorodnih fakulteta Sveučilišta u Zagrebu - Šumarskog fakulteta (ŠF), Fakulteta strojarstva i brodogradnje (FSB) te Hrvatskih studija (HRSTUD). Pretpostavljeno je da će studenti ŠF imati bolje razumijevanje problematike jer su bolje informirani o njoj kroz izvedbu studijskog programa. Uzorak je bio namjeran i prigodan, a ukupno je anketirano 247 ispitanika. Primijenjene su metode deskriptivne statistike, kao i hi-kvadrat i Kruskal-Wallis neparametarski testovi. Rezultati su pokazali da su studenti ŠF prema vlastitom mišljenju puno više upoznati s pojmom općekorisnih funkcija šuma i Naknade za njih od studenata drugih fakulteta. Međutim, pitanja znanja pokazala su da i oni imaju problema s prepoznavanjem tih funkcija, kao i namjena za koje se koristi Naknada. Ipak, gotovo uvijek je postojala statistički značajna razlika u odgovorima između studenata ŠF i studenata drugih dvaju fakulteta. Zaključuje se da informiranost donekle utječe na poznavanje problematike općekorisnih funkcija šuma, ali vjerojatno postoje i neki drugi čimbenici koji utječu na poznavanje i formiranje stava. U budućnosti je neophodno nastaviti istraživati razumijevanje i stavove različitih segmenata građanstva o općekorisnim funkcijama šuma i Naknadi, kako bi se razvili i primijenili prikladni instrumenti šumarske politike, a kojima bi cilj bio veće razumijevanje problematike i pozitivniji stav prema šumarskim aktivnostima u tom smislu.
\end{abstract}

KLJUČNE RIJEČl: anketa, studenti, naknada za općekorisne funkcije, Hrvatska, šumarska politika

\section{UVOD}

\section{INTRODUCTION}

O uslugama ekosustava (engl. ecosystem services), pokušajima njihovog sistematiziranja i vrednovanja u znanstvenoj i stručnoj javnosti raspravlja se već desetljećima (Constanza et al., 1997; Millenium Ecosystem Assessment, 2003;
Gómez-Baggethum et al., 2010). Općekorisne funkcije šuma, njihovo vrednovanje te osiguravanje financijskih sredstava za njih također su već dugi niz godina među najvažnijim temama hrvatskoga šumarstva. Tako još Zakon o šumama Socijalističke Republike Hrvatske (NN 20/1977) prepoznaje važnost šuma i njihovih općekorisnih funkcija

\footnotetext{
1 Dr. sc. Silvija Krajter Ostoić, znanstvena suradnica, predstojnica zavoda, Hrvatski šumarski institut, Zavod za međunarodnu znanstvenu suradnju - EFISEE, Zajčeva 28, 10000 Zagreb, Hrvatska, silvijak@sumins.hr

2 Dr. sc. Dijana Vuletić, znanstvena savjetnica, ravnateljica, Hrvatski šumarski institut, Cvjetno naselje 41, 10450 Jastrebarsko, Hrvatska, dijanav@sumins.hr
} 
te navodi što se smatra pod tim funkcijama. Ovaj zakon je prijeloman i u pokušaju da se uspostavi sustav boljega gospodarenja šumama na kršu, koje su nakon ukidanja Fonda za unapređenje šumarstva 1955. godine potpuno zanemarene i prepuštene degradaciji (Ivančević i Piškorić, 1986). Smatralo se da su baš te šume one kojima je glavna uloga osiguravanje općekorisnih funkcija šuma. Zakon je predvidio organizaciju takvog sustava i način da se osiguraju sredstva za obnovu šuma, pošumljavanje i protupožarnu zaštitu na kršu. Bili su to počeci onoga što danas nazivamo Naknadom za općekorisne funkcije šuma. Ipak, provedba nije napredovala kako je planirano, te su kraj 1970-ih i početak 1980-ih obilježeni brojnim raspravama i člancima u znanstvenim i stručnim krugovima o problemima vezanim za provedbu (Krnjak, 1977; Krnjak, 1979; Tomašević, 1979; Ivančević, 1983; Ivančević i Piškorić, 1986). Donesen je i novi Zakon o šumama (NN 54/1983), ali sustav osiguranja sredstava za općekorisne funkcije šuma na kršu nije u potpunosti zaživio onako kako je planirano još 1977. godine (Ivančević i Piškorić, 1986).

Početkom 1990-ih prijedlozi vrednovanja općekorisnih funkcija šuma i uspostave sustava naplate naknade kojima bi se sufinanciralo nihovo pružanje dobili su novi zamah (Prpić, 1992; Vuletić et al., 2010). Tako je Zakonom o šumama (NN 52/1990, čl. 70) propisano obvezno plaćanje naknade za korištenje općekorisnih funkcija šuma za sve pravne i fizičke osobe koje obavljaju privrednu djelatnost u $\mathrm{RH}$, a sustav vrednovanja, ili bolje rečeno procjene općekorisnih funkcija šuma donesen je u Pravilniku za uređivanje šuma (NN 52/1994). Propisana Naknada iznosila je 0,07\% ukupnog prihoda gospodarskog subjekta. Nakon toga Naknada je doživjela niz promjena u dijelu koji se odnosi na obveznike plaćanja i propisani postotak (Vuletić et al., 2010; Zakon o šumama 140/2005, 82/06, 80/2010, 25/2012, 68/2012 - Odluka i rješenje Ustavnog suda RH broj: U-I1408/2010 i dr. od 29. svibnja 2012). Promjene su posljedično proizvele i niz rasprava u stručnim krugovima (Uredništvo Šumarskog lista 2011, 2013; Tarnaj, 2012; Delač, 2013) i medijima (Barilar i Radusinović, 2013; Marić, 2013; Vukadinović, 2014; Poslovni dnevnik, 2013, 2014, 2015).

S druge strane začuđujuće je oskudan broj recentnih znanstvenih radova autora iz Hrvatske koji se bave ovom problematikom, a svakako je to u nesrazmjeru s važnosti općekorisnih funkcija i Naknade za njihovo osiguravanje. Stavovi o općekorisnim funkcijama šuma i njihovoj važnosti za građane, korištenju nedrvnih šumskih proizvoda i usluga te spremnost građana, uključujući i privatne šumoposjednike, na njihovu primjenu za pokretanje poduzetništva, tema su dva članka nastala kao rezultat znanstvenoistraživačkih projekata provedenih na Petrovoj gori i u Gospiću (Vuletić et al., 2009, 2011). Vuletić i dr. (2010) donose opsežan pregled vezan za zakonodavni okvir i plaćanje naknade za općekorisne funkcije šuma, probleme oko provedbe plaćanja, strukturu namjenskog utroška prikupljenih sredstava, kao i stavove obveznika plaćanja o Naknadi. Iako anketa obveznika plaćanja nije bila reprezentivna, inicijalni rezultati pokazuju da obveznici plaćanja znaju da plaćaju Naknadu, ali uglavnom ne znaju ili vrlo površno znaju njenu namjenu. Također, ne dobivaju povratnu informaciju o količini prikupljenog i utrošenog novca prema namjenama propisanim zakonom. S druge strane šumarski sektor smatra da je Naknada ionako premalena te da smanjenje iznosa Naknade ugrožava provedbu aktivnosti kojima ona služi.

Nešto je veća skupina radova koji se bave problematikom vrednovanja općekorisnih funkcija šuma. Tako uz već navedeni sustav procjene i ocjene općekorisnih funkcija šuma (Prpić, 1992) koji je ušao i u Pravilnik o uređivanju šuma (NN 54/1994) tu je i još nekoliko radova i studija koje se bavi isključivo turističko-rekreativnom funkcijom (Krznar et al., 2000; Horak et al., 2001; Tišma et al., 2002; Vuletić, 2002; Vuletić et al., 2006). Tako primjerice Krzar i dr. (2000) predlažu metodologiju vrednovanja turističko-rekreacijskih usluga šuma, a Tišma i dr. (2002) analiziraju turističku funkciju goranskih šuma metodom putnih troškova. Rezultati su služili kao ulaz za analizu troškova i koristi, čime se htjela pokazati opravdanost i dugoročna isplativost ulaganja u sanaciju najoštećenijih područja (Tišma et al., 2002). Osim turističko-rekreativne funkcije manji broj istraživanja bavi se vrednovanjem svih općekorisnih funkcija šuma, pa tako Sabadi i dr. (2005) računaju ukupnu ekonomsku vrijednost mediteranskih šuma, dok Krpina i dr. (2014) procjenjuju vrijednost općekorisnih funkcija šuma u Zadarskoj županiji. Kako je turizam važna gospodarska grana u Hrvatskoj, značaj ovih istraživanja je u činjenici da dokazuju koliko šume doprinose doživljaju posjetitelja, odnosno ukupnom turističkom proizvodu. Zbog rastućeg broja ljudi koji žive u urbanim sredinama, vrednovanje urbanih šuma, $t$. šuma u i oko gradova te ostaloga gradskog zelenila, sve više dobiva na važnosti, posebice kao argument za pojačano ulaganje u urbane šume i zelenu infrastrukturu. Nažalost, uočen je nedostatak takvih istraživanja u Hrvatskoj (Krajter Ostoić et al., 2013).

Na osnovi pregleda dosadašnje literature koja se bavi općekorisnim funkcijama šuma u Hrvatskoj, zaključujemo da se nedovoljno istraživanja bavi stavovima i percepcijom građana. $S$ druge strane o njihovom stavovima i informiranosti o toj problematici ovisi i podrška šumarskom sektoru u nastojanjima da osiguraju te funkcije, koristeći koristeći se pritom $\mathrm{i}$ instrumentima šumarske politike kao što je $\mathrm{Na}$ knada. Iako do sada nije bilo takvih istraživanja, smatramo da bi veća informiranost građana o općekorisnim funkcijama šuma i načinu njihova osiguravanja dovela do veće podrške javnosti šumarskom sektoru, pa i u pitanjima koja se odnose na izdvajanje financijskih sredstava koja se u posljednje vrijeme sve više dovode u pitanje. U stranoj literaturi nalazimo različite pristupe plaćanju, ovisno o tome radi li se o uspostavi plaćanja za okolišne usluge šume za veće područje (Farley et al., 2010; Koellner et al., 2011; Zbiden i 
Lee 2004) kada se radi o političkoj odluci kod koje građani najčešće nisu konzultirani ili kod plaćanja za određenu okolišnu uslugu kod koje se uspostavlja jasan odnos između korisnika i vlasnika, pa građani imaju jasnu sliku o tome što plaćaju. Najviše primjera iz ovog područja ima kod plaćanja za opskrbu vodom (Muradian et al., 2010; Fisher et al., 2010; Wendland et al., 2009), i zaštitom određenog područja radi očuvanja biološke raznolikosti te smanjivanja siromaštva (Prager et al., 2012; De Koning et al., 2011; Som= mervile et al., 2009; Kumar, 2005).

\section{METODOLOGIJA METHODOLOGY}

\section{Ciljevi istraživanja i hipoteze - Research goals and hypotheses}

Cilj istraživanja bio je analizirati utjecaj informiranosti na poznavanje problematike općekorisnih funkcija šuma. Istraživanje je zasnovano na hipotezi da veća informiranost vodi boljem poznavanju problematike općekorisnih funkcija šuma, boljem shvaćanju njihovih vrijednosti te lakšem prihvaćanju neophodnosti njihovog financiranja, pa i plaćanja od strane korisnika.

\section{Opis uzorka - Description of the sample}

Uzorci su izdvojeni iz studentske populacije triju fakuteta Sveučilišta u Zagrebu, pri čemu su fakulteti odabrani tako da pripadaju različitim područjima znanosti - Šumarski fakultet (ŠF) iz područja biotehničkih znanosti, Fakultet strojarstva i brodogradnje (FSB) iz područja tehničkih znanosti te Hrvatski studiji (HRSTUD) koji u ovom istraživanju predstavljaju društveno-humanističke znanosti. Pretpostavka je da će studenti ŠF biti bolje informirani o općekorisnim funkcijama šuma te stoga pokazati i bolje poznavanje problematike.

U skladu s ciljem istraživanja i realnim mogućnostima, uzorak je istovremeno namjeran (engl. purposeful sampling) i prigodan (engl. convenience sampling) (Milas, 2009). Namje- ran je stoga što smo ciljano odabrali fakultete koji pripadaju različitim područjima znanosti, a prigodan jer smo mogli odabrati neke druge fakultete iz istog područja znanosti. Primjerice, umjesto studenata FSB istraživanje smo mogli provesti na studentima Fakulteta elektrotehnike i računarstva ili smo umjesto HRSTUD mogli odabrati Filozofski fakultet. Studente smo odabrali kao ciljanu populaciju jer predstavljaju segment građanstva i budući su nositelji društva, pa nam je njihovo mišljenje o ovoj problematici vrlo važno. Također, odabirom različitih fakulteta lako smo mogli kontrolirati njihovu potencijalnu informiranost. Ovakvo uzorkovanje ne može dati reprezentativne rezultate, odnosno na osnovi dobivenih rezultata ne možemo donositi generalne zaključke. Ipak, ovakvi rezultati služe kao osnova i daju smjernice za daljnja istraživanja, posebice kada se uzme u obzir da sličnih istraživanja u Hrvatskoj do sada nije bilo.

Ukupni uzorak sačinjavalo je 247 ispitanika s različitim udjelima na pojedinim fakultetima (Tablica 1). Na svakom fakultetu anketirana je jedna skupina studenata starijih godina, na način da su predavači triju fakulteta podijelili studentima ankete na početku predavanja ili vježbi. Prema spolu u istraživanju je ukupno sudjelovalo 160 muškaraca i 85 žena, pri čemu je očekivano udio muškaraca na ŠF i FSB bio veći nego na HRSTUD, gdje su prevladavale žene. Kada se radi o prihodu kućanstva ispitanika, on je kod ispitanika FSB bio statistički značajno veći u odnosu na ispitanike drugih dvaju fakulteta (Tablica 1).

\section{Metoda - Method}

Primijenjena je metoda ankete (Milas, 2009; de Vaus, 2005) koja je svoju primjenu našla i u šumarstvu (e.g. Halder et al., 2016; Stevanov et al., 2015). Anketa je provedena u svibnju 2013. godine te se sastojala od 13 pitanja, pri čemu su se tri odnosila na općekorisne funkcije šuma, šest na Naknadu za općekorisne funkcije šuma te ostala na samog ispitanika (dob, spol, zanimanje i prihod kućanstva). Pitanja vezana za općekorisne funkcije šuma odnosila su se na upoznatost s pojmom općekorisnih funkcija šuma, prepozna-

Tablica 1. Struktura uzorka s obzirom na pripadnost pojedinom fakultetu i spol ispitanika $(n=247)$

Table 1. Sample according to association to a certain faculty, sex and household income $(N=247)$

Šumarski fakultet (ŠF)

Faculty of Forestry (FoF)

$\begin{array}{lc}\begin{array}{l}\text { Udio ispitanika } \\ \text { (Share of respondents) }\end{array} & 26,7 \% \\ \text { Spol (Sex) } & \begin{array}{c}\text { Muško (Male) }-68,2 \% \\ \text { Žensko (Female })-31,8 \% \\ \\ \end{array} \\ & <3000 \text { HRK }-7,3 \% \\ \text { Prihod kućanstva } & 5000-4999 \text { HRK }-15,5 \% \\ \text { (Household income) } & 7000-9999 \text { HRK }-21,8 \% \\ & 10 \text { HRK }-21,8 \% \\ & >=15000 \text { HRK }-12,7 \%\end{array}$

Fakultet strojarstva i brodogradnje (FSB) Faculty of Mechanical Engineering and Naval Architecture (FMENA)

$46,6 \%$

Muško (Male) - 87,6\%

Žensko (Female) - 12,4\%

$<3000$ HRK $-9,0 \%$

3 000-4 999 HRK $-3,0 \%$

5 000-6 999 HRK $-18,0 \%$

$7000-9999$ HRK $-19,0 \%$

10 000-14 999 HRK $-27,0 \%$

$>=15000 \mathrm{HRK}-24,0 \%$
$26,7 \%$

Hrvatski studifi (HRSTUD) Centre for Croatian Studies (CCS)

Muško (Male) - 24,2\%

Žensko (Female) - 75,8\%

$<3000$ HRK - 20,0\%

3 000-4 999 HRK - 10,8\%

5 000-6 999 HRK - 23,1\%

7 000-9 999 HRK - 20,0\%

10 000-14 999 HRK - 16,9\%

$>=15000$ HRK $-9,2 \%$ 
vanje pojedinih funkcija, te najvažniju funkciju za ispitanika osobno. Pitanja vezana za Naknadu za općekorisne funkcije šuma odnosila su se na upoznatost s postojanjem Naknade, poznavanje činjenica o Naknadi, poput obveznika plaćanja, raspolaganja sredstvima, poznavanje namjena za koje Naknada služi, te slaganje s tvrdnjama vezanim za namjensko trošenje, transparentnost trošenja ili uopće potrebu za ovakvim instrumentom. Na kraju su ispitanici trebali navesti za koju bi općekorisnu funkciju šuma bili spremni izdvojiti iznos po želji. Pitanja su bila zatvorenog (odgovori da ili ne, niz ponuđenih odgovora ili Likertova skala) i otvorenog tipa (npr. najvažnija funkcija). Također, neka pitanja su imala samo jedan mogući točan odgovor (npr. odgovor na pitanje koja institucija raspolaže sredstvima Naknade), dok su druga imala mogućnost više točnih odgovora (npr. pitanje vezano za prepoznavanje općekorisnih funkcija šuma ili prepoznavanje aktivnosti koje se financiraju iz Naknade).

\section{Statistička analiza - Statistical analysis}

Osnovna analiza uključivala je primjenu deskriptivne statistike (frekvencije i postotci). Kako nas je zanimalo ne samo u kojoj mjeri studenti pojedinih fakulteta poznaju problematiku općekorisnih funkcija šuma, već i postoji li statistički značajna razlika među njima, dalje smo koristili neparametarske testove, jer se radi o neprobabilističkim uzorcima. U tu svrhu korišteni su hi-kvadrat i KruskalWallis test. Od post-hoc testova korišteni su Fisherov i Pearsonov. Statistička analiza rađena je u programskom paketu SPSS 20.0. (IBM Corp., 2011).

\section{REZULTATI}

\section{RESULTS}

\section{Poznavanje općekorisnih funkcija šuma - Recognition of forest ecosystem services}

Prvo pitanje odnosilo se na poznavanje pojma općekorisnih funkcija šuma u smislu jesu li ispitanici prema vlastitom mišljenju upoznati s ovim pojmom ili ne. Rezultat je pokazao da su studenti ŠF prema vlastitom mišljenju puno više upoznati s pojmom od studenata drugih fakulteta (Slika 1), a rezultati hi-kvadrattesta pokazali su da postoji i statistički značajna razlika među studentima pojedinih fakulteta (vrijednost $=98,932 ; p=0,000)$. Fisherov test pokazao je da statistički značajna razlika postoji među studenatima ŠF i FSB te ŠF i HRSTUD (u oba slučaja p=0,000).

Sljedeće pitanje odnosilo se na prepoznatost pojedinih općekorisnih funkcija šuma kao takvih, pri čemu su kao mogući odgovori u upitniku bile pobrojane sve funkcije onako kako su navedene u Zakonu o šumama (NN 140/2005). Zanimalo nas je koliko je pojedina funkcija prepoznata i u kojem postotku (Tablica 1). U tablici su umjesto punih naziva funkcija upotrijebljeni kodovi.

Iz tablice je vidljivo da ni jedna funkcija nije bila apsolutno prepoznata. Funkcije koje su studenti ŠF najviše prepoznali bile su zaštita od erozije, rekreacijska, pročišćavanje zraka, ublažavanje klime te proizvodnja kisika i to upravo tim redoslijedom. Najmanje su prepoznate uloga šuma u razvoju lokalne zajednice, uloga u obrani zemlje te uloga šuma u zaštiti prirode. Studenti FSB najviše su prepoznali funkcije proizvodnje kisika, ublažavanja klime, pročišćavanja zraka, zdravstvenu te funkciju očuvanja bioraznolikosti. Iste funkcije najviše se prepoznali i studenti HRSTUD, ali s nešto izmijenjenim redoslijedom (Tablica 2). Kad se radi o najmanje prepoznatim funkcijama i za studente FSB i HRSTUD to su bile uloga u obrani zemlje, uloga u razvoju lokalne zajednice te zaštita od bujica.

Osim prepoznatosti pojedine funkcije zanimalo nas je postoji li statistički značajna razlika u prepoznatosti pojedinih funkcija među studentima različitih fakulteta. Rezultati hikvadrat testa pokazali su da postoji za devet od 17 funkcija. Također nas je zanimalo između studenata kojih fakulteta postoji statistički značajna razlika u prepoznavanju pojedine funkcije (Tablica 3). Rezultati su pokazali da gotovo uvijek za navedene funkcije postoji statistički značajna ra-

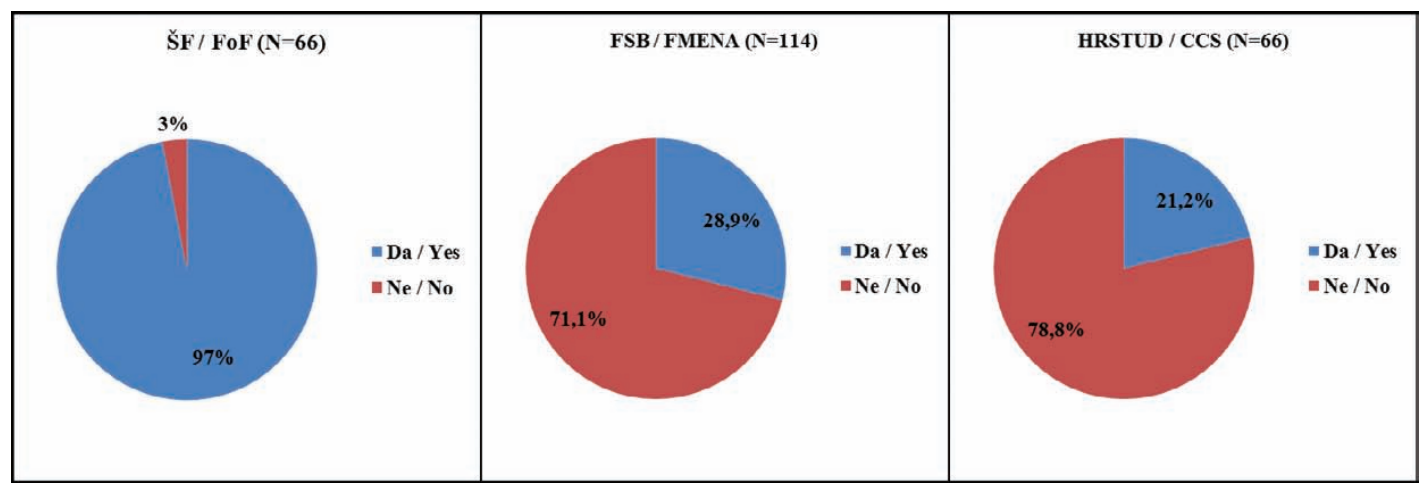

Slika 1. Upoznatost studenata s pojmom općekorisnih funkcija šuma

Figure. 1. Students being informed about forest ecosystem services 
Tablica 2. Prepoznatost pojedinih općekorisnih funkcija šuma po fakultetima (pet najčešće prepoznatih označeno je bold) Table 2. Recognition of forest ecosystem services according to association to a certain faculty (five most recognised are in bold)

\begin{tabular}{|c|c|c|c|}
\hline $\begin{array}{l}\text { OKFŠ } \\
\text { Forest ecosystem services }\end{array}$ & $\begin{array}{c}\text { ŠF } \\
\text { Faculty of Forestry }\end{array}$ & $\begin{array}{c}\text { FSB } \\
\text { Faculty of Mechanical Engineering } \\
\text { and Naval Architecture }\end{array}$ & $\begin{array}{c}\text { HRSTUD } \\
\text { Centre for Croatian Studies }\end{array}$ \\
\hline $\begin{array}{l}\text { Zaštita od erozije } \\
\text { Protection from erosion }\end{array}$ & $97,0 \%$ & $72,2 \%$ & $44,0 \%$ \\
\hline $\begin{array}{l}\text { Zaštita od bujica } \\
\text { Protection from torrents }\end{array}$ & $75,8 \%$ & $41,7 \%$ & $42,4 \%$ \\
\hline $\begin{array}{l}\text { Pročišćavanje vode } \\
\text { Water purification }\end{array}$ & $75,8 \%$ & $66,1 \%$ & $63,3 \%$ \\
\hline $\begin{array}{l}\text { Ublažavanje klime } \\
\text { Climate mitigation }\end{array}$ & $86,4 \%$ & $79,1 \%$ & $74,2 \%$ \\
\hline $\begin{array}{l}\text { Pročišćavanje zraka } \\
\text { Air purification }\end{array}$ & $87,9 \%$ & $78,3 \%$ & $72,2 \%$ \\
\hline $\begin{array}{l}\text { Estetika } \\
\text { Aesthetics }\end{array}$ & $81,8 \%$ & $66,1 \%$ & $47,0 \%$ \\
\hline $\begin{array}{l}\text { Zdravlje } \\
\text { Health }\end{array}$ & $83,3 \%$ & $76,5 \%$ & $75,8 \%$ \\
\hline $\begin{array}{l}\text { Rekreacija } \\
\text { Recreation }\end{array}$ & $89,4 \%$ & $59,1 \%$ & $50,0 \%$ \\
\hline $\begin{array}{l}\text { Turizam } \\
\text { Tourism }\end{array}$ & $80,3 \%$ & $54,8 \%$ & $50,0 \%$ \\
\hline $\begin{array}{l}\text { Genofond } \\
\text { Protection of genetic resources }\end{array}$ & $66,7 \%$ & $61,7 \%$ & $66,7 \%$ \\
\hline $\begin{array}{l}\text { Bioraznolikost } \\
\text { Biodiversity }\end{array}$ & $75,8 \%$ & $75,7 \%$ & $83,3 \%$ \\
\hline $\begin{array}{l}\text { Zaštita prirode } \\
\text { Nature protection }\end{array}$ & $68,2 \%$ & $58,3 \%$ & $63,6 \%$ \\
\hline $\begin{array}{l}\text { Vezivanje uglijika } \\
\text { Carbon sequestration }\end{array}$ & $72,7 \%$ & $63,5 \%$ & $59,1 \%$ \\
\hline $\begin{array}{l}\text { Kisik } \\
\text { Oxygen }\end{array}$ & $83,3 \%$ & $96,5 \%$ & $89,4 \%$ \\
\hline $\begin{array}{l}\text { Intrinzična vrijednost } \\
\text { Intrinsic value }\end{array}$ & $72,7 \%$ & $54,8 \%$ & $53,0 \%$ \\
\hline $\begin{array}{l}\text { Obrana zemlje } \\
\text { Defence of the country }\end{array}$ & $60,6 \%$ & $31,3 \%$ & $33,3 \%$ \\
\hline $\begin{array}{l}\text { Lokalna zajednica } \\
\text { Value for local community }\end{array}$ & $57,6 \%$ & $33,0 \%$ & $25,8 \%$ \\
\hline
\end{tabular}

zlika između ŠF i FSB te ŠF i HRSTUD (izuzetak je funkcija proizvodnje kisika), ali skoro nikad (izuzetak je estetska funkcija) između FSB i HRSTUD.

\section{Poznavanje Naknade za općekorisne funkcije šuma - Knowledge of the Payments for ecosystem services}

Prema vlastitom mišljenju studenti ŠF su znatno više upoznati s postojanjem Naknade za općekorisne funkcije šuma od studenata ostalih dvaju fakulteta, što se pokazalo i statistički značajnim (vrijednost= 193,999; p=0,000).

Nadalje, studenti su trebali prepoznati aktivnosti koje se financiraju iz Naknade za OKFŠ, pri čemu su aktivnosti, odnosno namjene, bile navedene u upitniku onako kako je to propisano u Zakonu o šumama (NN 140/2005). Nijedna namjena nije bila apsolutno prepoznata, pri čemu je pošumljavanje bilo najprepoznatije među studentima sva tri fakulteta (Tablica 4). Gospodarenje šumama na kršu te sanacija i obnova ugroženih šuma su među tri najprepoznatije namjene među studentima ŠF, od čega je potonja među tri najprepoznatije namjene i među studentima drugih fakulteta. Za razliku od studenata ŠF čuvanje šuma kao namjenu Naknade znatno više su prepoznali studenti FSB i HRSTUD, gdje je ta aktivnost među tri najprepoznatije. Kad se analiziraju tri najslabije prepoznate aktivnosti, za studente svih triju fakulteta to su aktivnosti izrade programa gospodarenja privatnim šumama i izgradnje šumskih prometnica. Studenti ŠF najslabije su prepoznali kupnju šuma i šumskog zemljišta kao jednu od namjena Naknade, dok je za studente ostala dva fakulteta to bilo financiranje rada vatrogasnih zajednica na kršu (Tablica 4). 
Tablica 3. Rezultati hi-kvadrat testa za pojedine općekorisne funkcije šuma s obzirom na razlike među fakultetima (statistički značajne razlike prikazane su bold)

Table 3. Results of Chi-square test for a specific forest ecosystem service based on differences between students affiliated with certain faculties (ŠFFaculty of Forestry, FSB- Faculty of Mechanical Engineering and Naval Architecture, HRSTUD- Centre for Croatian Studies) (statistically significant differences are in bold)

\begin{tabular}{|c|c|c|c|c|c|c|c|c|c|}
\hline \multirow[b]{2}{*}{$\begin{array}{l}\text { OKFŠ } \\
\text { FES }\end{array}$} & \multicolumn{3}{|c|}{ ŠF x FSB } & \multicolumn{3}{|c|}{ FSB $x$ HRSTUD } & \multicolumn{3}{|c|}{ ŠF x HRSTUD } \\
\hline & $\begin{array}{l}\text { Vrijednost } \\
\text { Value }\end{array}$ & $\begin{array}{c}\text { Stupnjevi } \\
\text { slobode } \\
\text { df }\end{array}$ & $\begin{array}{l}\text { Fisher's } \\
\text { Exact T }\end{array}$ & $\begin{array}{l}\text { Vrijednost } \\
\text { Value }\end{array}$ & $\begin{array}{c}\text { Stupnjevi } \\
\text { slobode } \\
\text { df }\end{array}$ & $\begin{array}{l}\text { Fisher's } \\
\text { Exact T }\end{array}$ & $\begin{array}{l}\text { Vrijednost } \\
\text { Value }\end{array}$ & $\begin{array}{c}\text { Stupnjevi } \\
\text { slobode } \\
\text { df }\end{array}$ & $\begin{array}{l}\text { Fisher's } \\
\text { Exact T }\end{array}$ \\
\hline $\begin{array}{l}\text { Protuerozijska } \\
\text { Protection from erosion }\end{array}$ & 16,900 & 1 & .000 & .608 & 1 & .270 & 20,370 & 1 & .000 \\
\hline $\begin{array}{l}\text { Zaštita od bujica } \\
\text { Protection from torrents }\end{array}$ & 19,545 & 1 & .000 & .008 & 1 & .526 & 15,168 & 1 & .000 \\
\hline $\begin{array}{l}\text { Estetika } \\
\text { Aesthetics }\end{array}$ & 5,128 & 1 & .017 & 6,341 & 1 & .009 & 17,479 & 1 & .000 \\
\hline $\begin{array}{l}\text { Rekreacija } \\
\text { Recreation }\end{array}$ & 18,347 & 1 & .000 & 1,417 & 1 & .150 & 24,248 & 1 & .000 \\
\hline $\begin{array}{l}\text { Turizam } \\
\text { Tourism }\end{array}$ & 11,867 & 1 & .000 & .385 & 1 & .321 & 13,347 & 1 & .000 \\
\hline $\begin{array}{l}\text { Kisik } \\
\text { Oxygen }\end{array}$ & 9,596 & 1 & .003 & 3,732 & 1 & .056 & 1,029 & 1 & .224 \\
\hline $\begin{array}{l}\text { Intrinzična vrijednost } \\
\text { Intrinsic value }\end{array}$ & 5,693 & 1 & .012 & .052 & 1 & .471 & 5,485 & 1 & .015 \\
\hline $\begin{array}{l}\text { Obrana } \\
\text { Defence of the country }\end{array}$ & 14,781 & 1 & .000 & .079 & 1 & .452 & 9,854 & 1 & .001 \\
\hline $\begin{array}{l}\text { Lokalna zajednica } \\
\text { Value for local community }\end{array}$ & 10,361 & 1 & .001 & 1,052 & 1 & .196 & 13,745 & 1 & .000 \\
\hline
\end{tabular}

Tablica 4. Prepoznatost pojedinih aktivnosti koje se financiraju iz Naknade za općekorisne funkcije šuma u Hrvatskoj (tri najčešće prepoznate označene su bold)

Table 4. Recognition of activities funded from the Payment for forest ecosystem services (PES) in Croatia (three most recognised are in bold)

\begin{tabular}{|c|c|c|c|}
\hline $\begin{array}{l}\text { Aktivnost koja se financira iz Naknade } \\
\text { Activity funded from the PES }\end{array}$ & $\begin{array}{l}\text { ŠF } \\
\text { Faculty of } \\
\text { Forestry }\end{array}$ & $\begin{array}{c}\text { FSB } \\
\text { Faculty of Mechanical Engineering and } \\
\text { Naval Architecture }\end{array}$ & $\begin{array}{l}\text { HRSTUD } \\
\text { Centre for Croatian } \\
\text { Studies }\end{array}$ \\
\hline $\begin{array}{l}\text { Gospodarenje šumama na kršu } \\
\text { Management of forests on karst }\end{array}$ & $69,7 \%$ & $24,3 \%$ & $22,7 \%$ \\
\hline $\begin{array}{l}\text { Rad vatrogasnih zajednica na kršu } \\
\text { Funding of firefighting units on karst }\end{array}$ & $37,9 \%$ & $9,6 \%$ & $9,1 \%$ \\
\hline $\begin{array}{l}\text { Znanstvenoistraživački rad u šumarstvu } \\
\text { Forestry research }\end{array}$ & $30,3 \%$ & $28,7 \%$ & $39,4 \%$ \\
\hline $\begin{array}{l}\text { Razminiravanje šuma } \\
\text { Forest demining }\end{array}$ & $24,2 \%$ & $34,8 \%$ & $31,7 \%$ \\
\hline $\begin{array}{l}\text { Pošumljavanje } \\
\text { Afforestation }\end{array}$ & $72,7 \%$ & $85,2 \%$ & $81,8 \%$ \\
\hline $\begin{array}{l}\text { Izgradnja šumskih prometnica } \\
\text { Forest roads }\end{array}$ & $22,7 \%$ & $7,8 \%$ & $10,6 \%$ \\
\hline $\begin{array}{l}\text { Kupnja šuma i šumskog zemljišta } \\
\text { Purchasing forests and forest land }\end{array}$ & $9,1 \%$ & $21,7 \%$ & $13,6 \%$ \\
\hline $\begin{array}{l}\text { Sanacija i obnova ugroženih šuma } \\
\text { Recovery and renewal of threatened forests }\end{array}$ & $69,7 \%$ & $56,5 \%$ & $68,2 \%$ \\
\hline $\begin{array}{l}\text { Zaštita šuma od štetnika } \\
\text { Pest control }\end{array}$ & $31,8 \%$ & $38,3 \%$ & $51,5 \%$ \\
\hline $\begin{array}{l}\text { Čuvanje šuma } \\
\text { Forest keeping }\end{array}$ & $33,3 \%$ & $71,3 \%$ & $69,7 \%$ \\
\hline $\begin{array}{l}\text { Programi gospodarenja privatnim šumama } \\
\text { Forest management plans for private forests }\end{array}$ & $7,6 \%$ & $13,0 \%$ & $10,6 \%$ \\
\hline
\end{tabular}

Zanimalo nas je i postoji li statistički značajna razlika u prepoznavanju pojedinih namjena među studentima triju fakulteta te između kojih fakulteta. Rezultati hi-kvadrat testa pokazali su da postoji statistički značajna razlika među fakultetima u prepoznavanju sljedeće četiri aktivnosti koje se mogu financirati iz Naknade, a to su gospodarenje šumama 


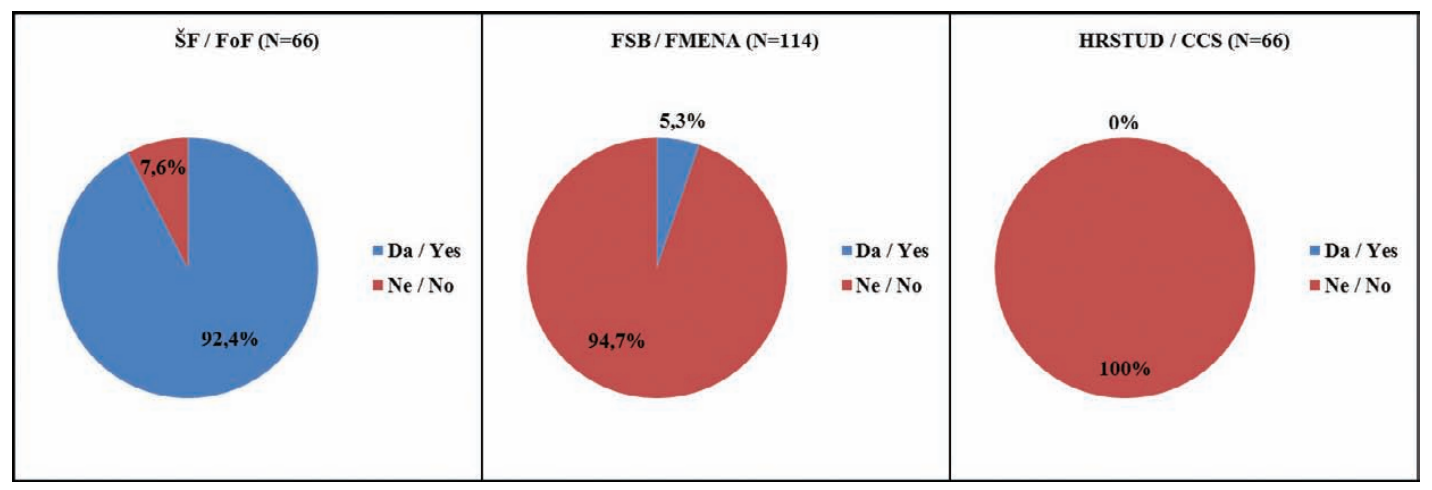

Slika 2. Upoznatost studenata s postojanjem Naknade za općekorisne funkcije šuma u Hrvatskoj

Figure 2. Students being informed about the existance of the Payment for forest ecosystem services in Croatia

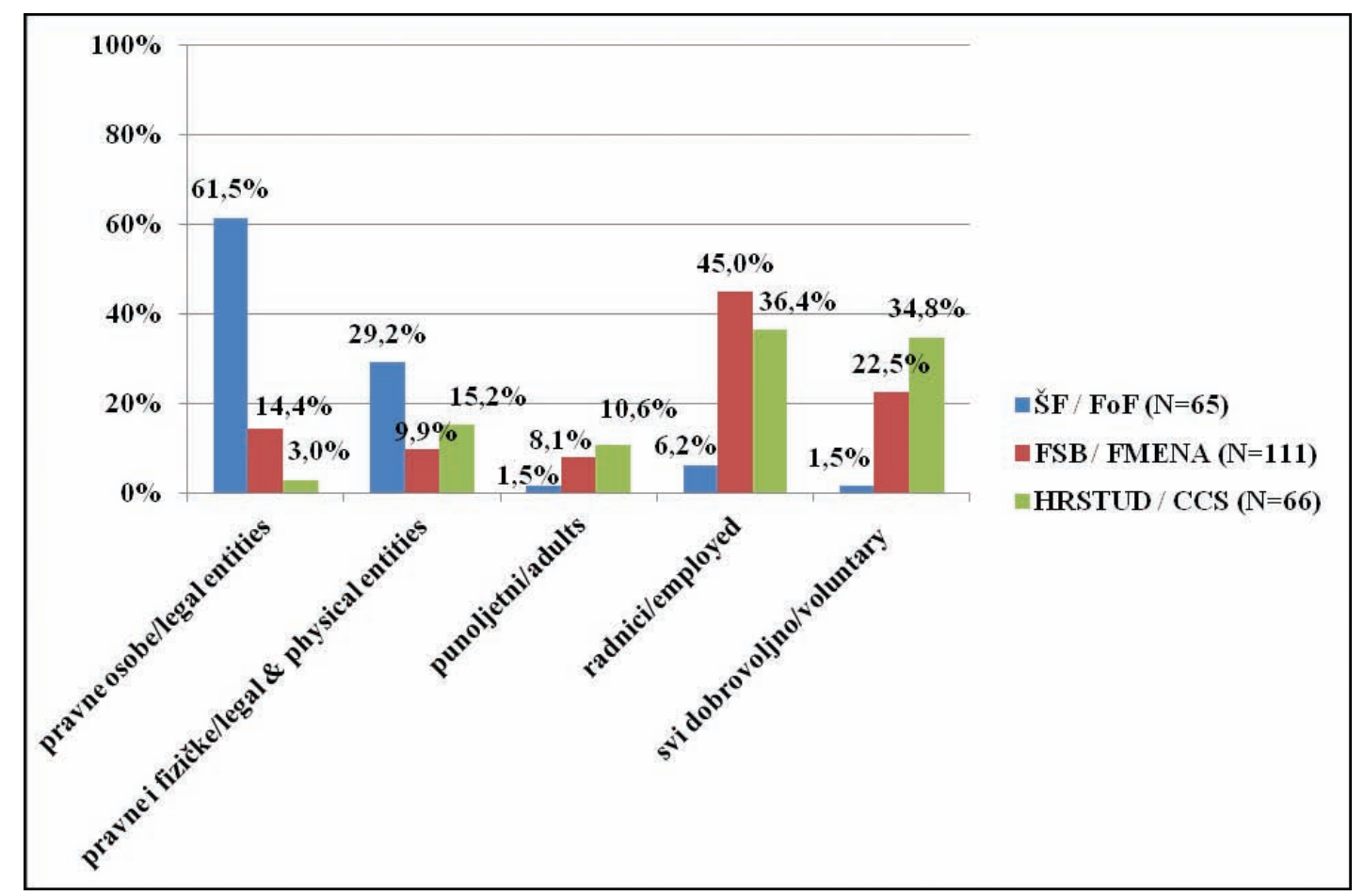

Slika 3. Razdioba odgovora na pitanje o obveznicima plaćanja Naknade za općekorisne funkcije šuma u Hrvatskoj

Figure 3. Distribution of responses about who are the obligatory payers of the Payment for forest ecosystem services in Croatia

na kršu (vrijednost=44,333), financiranje vatrogasnih zajednica na kršu (vrijednost=27,816), čuvanje šuma (vrijednost $=28,389$, u sva tri slučaja $\mathrm{p}=0,000$ ) te izgradnja šumskih prometnica (vrijednost $=8,794, \mathrm{p}=0,012$ ). Fisherov post-hoc test pokazao je da za te aktivnosti uvijek postoji statistički značajna razlika između studenata ŠF i ostalih fakulteta, dok uopće ne postoji između studenata FSB i HRSTUD.

Na pitanje tko su obveznici plaćanja Naknade za općekorisne funkcije šuma ispitanici su na pet ponuđenih mogućnosti dali raznolike odgovore (Slika 3). Rezultati pokazuju da je točan odgovor dalo samo $29,2 \%$ studenata ŠF, 9,9\% sa FSB i 15,2\% sa HRSTUD. Hi-kvadrat test pokazao je da postoji statistički značajna razlika u odgovorima na ovo pitanje među studentima triju fakulteta (vrijednost=106,307; $\mathrm{p}=0,000)$, pri čemu je postojala statistički značajna razlika između ŠF i FSB (vrijednost=73,131) te ŠF i HRSTUD (vrijednost $=76,123$; u oba slučaja $\mathrm{p}=0,000)$ te između FSB i HRSTUD (vrijednost=9,584; $\mathrm{p}=0,048$ ).

$\mathrm{Na}$ pitanje koja institucija raspolaže prikupljenim sredstvima, kao odgovor bilo je ponuđeno šest mogućnosti od kojih je samo jedna bila točna. Kao i u prethodnom slučaju ispitanici su dali šarolike odgovore (Slika 4). Rezultati pokazuju da je na pitanje točno odgovorilo samo 41,5\% studenata ŠF, 26,8\% studenata FSB i 19,7\% studenata HRSTUD. U odgovorima na ovo pitanje postoji statistički značajna razlika među ispitanicima različitih fakulteta i to između ŠF i FSB (vrijednost=21,366; $p=0,001$ ) te između ŠF i HRSTUD (vrijednost=31,424; $\mathrm{p}=0,000$ ). 


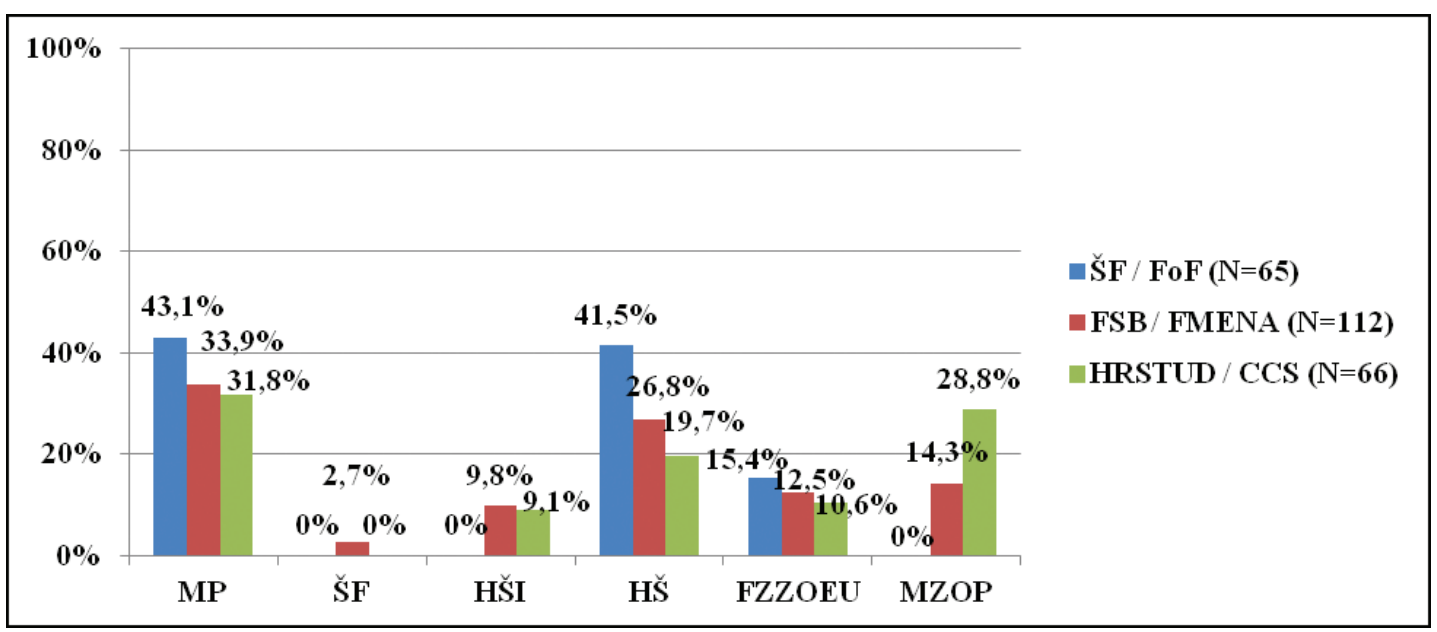

Slika 4. Razdioba odgovora na pitanje o instituciji koja raspolaže sredstvima Naknade za općekorisne funkcije šuma (MP- Ministarstvo poljoprivrede, ŠF- Šumarski fakultet, HŠI- Hrvatski šumarski institut, FZZOEU- Fond za zaštitu okoliša i energetsku učinkovitost, MZOP- Ministarstvo zaštite okoliša i prirode)

Figure 4. Distribution of responses about the institution who is reponsible for purposeful spending of the Payment for forest ecosystem services (MPMinistry of Agriculture), ŠF- Faculty of Forestry, HŠl- Croatian Forest Research Institute, HŠ- Croatian Forests Ltd., FZZOEU- The Environmental Protection and Energy Efficiency Fund, MZOP- Ministry of Environmental and Nature Protection, FoF- Faculty of Forestry, FMENA- Faculty of Mechanical Engineering and Naval Architecture, CCS- Centre for Croatian Studies)

Stavovi o Naknadi za korištenje općekorisnih funkcija šuma - Attitudes towards the Payment for forest ecosystem services in Croatia

Ispitanici su razinu slaganja sa četiri tvrdnje koje se odnose na Naknadu za općekorisne funkcije šuma iskazali na Likertovoj skali vrijednosti od 1- „u potpunosti se ne slažem“ do 5 - „u potpunosti se slažem“, gdje je 3- „niti se slažem, niti se ne slažem“. Ispitanici su imali i mogućnost odgovoriti s „ne znam“. Ti odgovori tumačeni su na način da ispitanik nema mišljenje o navedenoj temi. Rezultati su pokazali da ispitanici sa FSB i HRSTUD puno češće nisu imali mišljenje o pojedinim izjavama u odnosu na ispitanike sa ŠF (Slike 5-8). Prema Kruskal-Wallis testu postoji statistički značajna razlika između ispitanika sa ŠF i HRSTUD (vrijednost $=7,979 ; p=0,005$ ) s obzirom na to imaju li ili nemaju mišljenje o tvrdnji da se Naknada troši namjenski (Slika 5) te između ispitanika sa ŠF i FSB (vrijednost=7,086; p=0,008) kad se radi o tvrdnji da Naknadu treba ukinuti (Slika 8). Za tvrdnje o transparentnosti trošenja i doprinosa Naknade unaprjeđenju stanja šuma u RH nije postojala statistički značajna razlika između ispitanika različitih fakulteta s obzirom na postojanje ili odsutnost mišljenja o navedenoj temi.

Ako se uzmu u obzir samo oni koji su izrazili razinu svojega slaganja s navedenim tvrdnjama vezanim za Naknadu za općekorisne funkcije šuma, prosječna ocjena slaganja

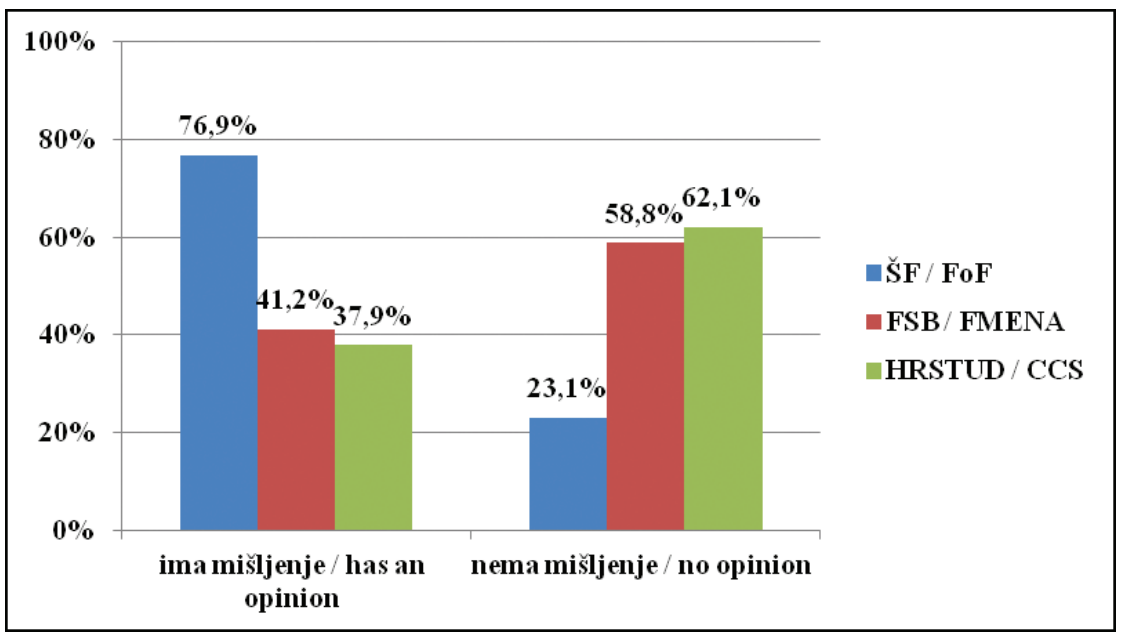

Slika 5. „Naknada za općekorisne funkcije šuma troši se namjenski.“

Figure 5. "The Payment for forest ecosystem services is spent purposefully." 


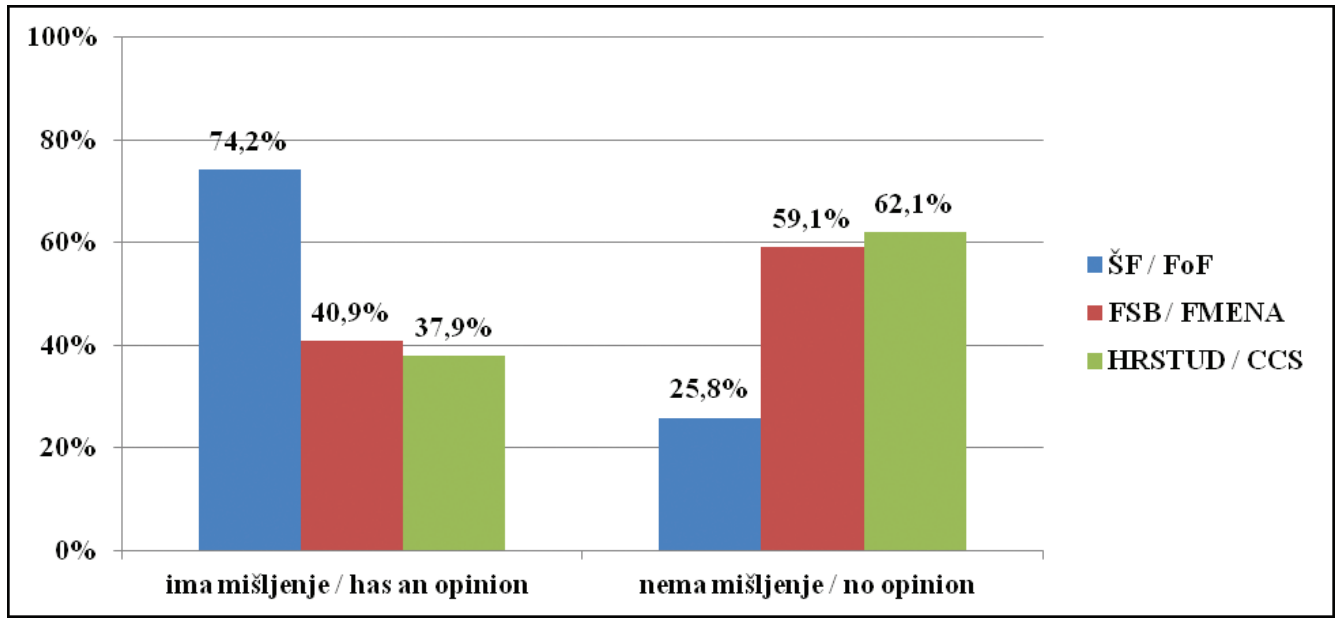

Slika 6. „Naknada za općekorisne funkcije šuma troši se transparentno.“

Figure 6. „The Payment for forest ecosystem services is spent transparently."

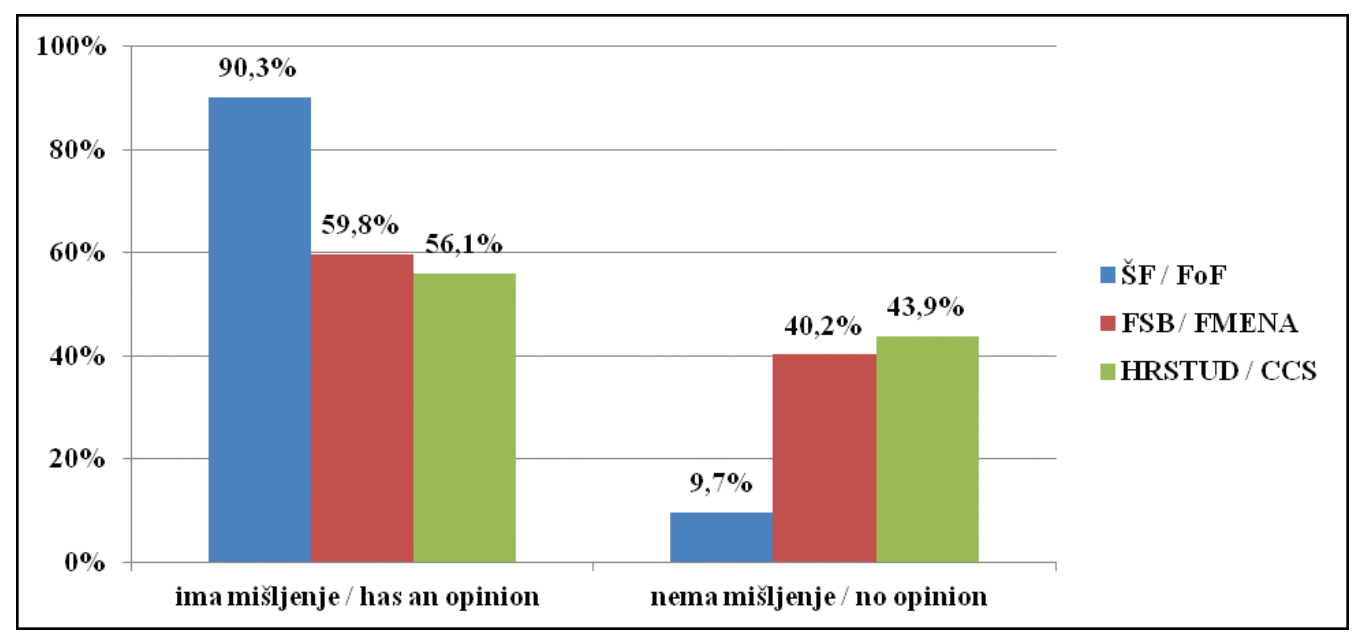

Slika 7. „Sredstva iz Naknade za općekorisne funkcije šuma doprinose unaprjeđenju stanja šuma u RH.“

Figure 7. "The Payment for forest ecosystem services contributes to improvement of the state of forests in Croatia.

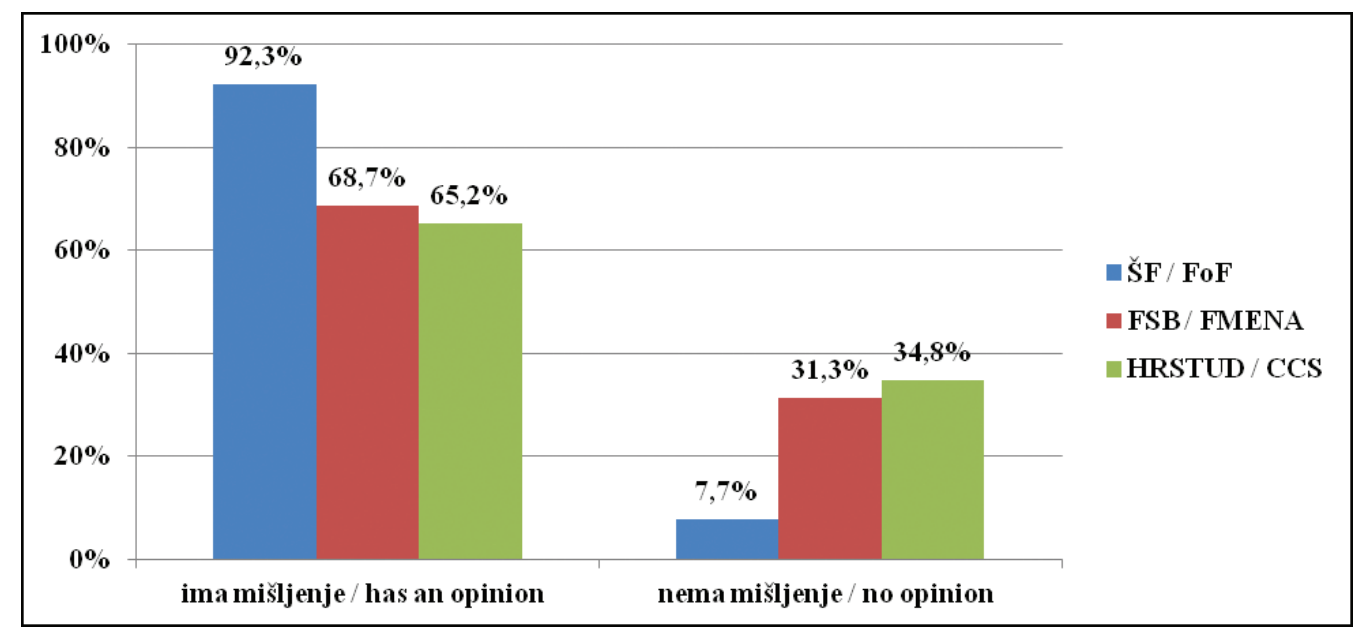

Slika 8. „Mislim da bi trebalo ukinuti plaćanje Naknade za općekorisne funkcije šuma.“

Figure 8. „In my opinion the Payment for forest ecosystem services should be abolished." 


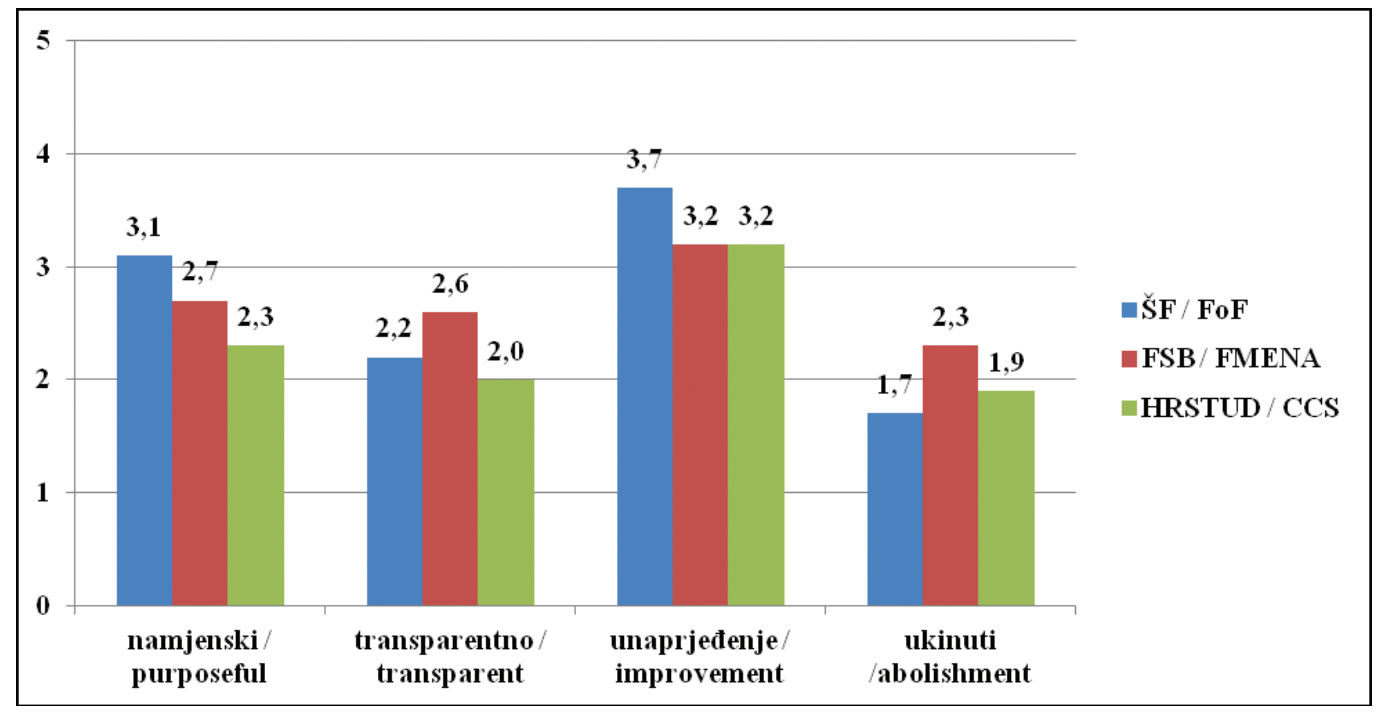

Slika 9. Prosječna ocjena slaganja s tvrdnjama vezanim za Naknadu za općekorisne funkcije šuma

Figure 9. Average opinion related to statements about whether the Payment for forest ecosystem services is being purposefully and transparently spent, contributes to improvement of forest ecosystem services or should be abolished

pokazuje da se ispitanici triju fakulteta manje-više ne slažu s tvrdnjom da se sredstva Naknade troše namjenski i transparentno (Slika 9). Kad se radi o ocjeni slaganja s tvrdnjom da sredstva Naknade doprinose unaprjeđenju stanja šuma u RH, studenti HŠ se prosječno slažu s tvrdnjom, dok su studenti ostalih fakulteta prosječno niti slažu, niti ne slažu. Također, ispitanici se prosječno ne slažu s tvrdnjom da Naknadu treba ukinuti (Slika 9).

\section{RASPRAVA I ZAKLJUČCI DISCUSSION AND CONCLUSIONS}

Kada se radi o poznavanju pojma općekorisnih funkcija šuma, gotovo svi ispitanici ŠF izjavili su da su upoznati s pojmom, u odnosu na samo jednu trećinu ispitanika FSB, odnosno jednu petinu ispitanika HRSTUD (Slika 1). Razlika među studentima ŠF i FSB te ŠF i HRSTUD pokazala se statistički značajnom. To je bilo i očekivano, s obzirom da su studenti ŠF kroz nastavu iz različitih predmeta informirani o pojmu općekorisnih funkcija šuma, koje su to funkcije koje smatramo općekorisnima, kako se mogu vrednovati te o načinu njihova financiranja u Hrvatskoj, za razliku od studenata FSB i HRSTUD koji tu temu ne obrađuju u sklopu svojih programa. Ipak, kada su trebali prepoznati pojedine općekorisne funkcije kao takve, pokazalo se da poteškoće s tim imaju i studenti ŠF, s obzirom da ni jedna funkcija nije bila apsolutno prepoznata. Prepoznatost pojedine funkcije za studente ŠF ipak je bila iznad 50\%, dok je kod studenata FSB i HRSTUD za neke funkcije i manja od 30\% (Tablica 2). Kako su studenti ŠF informirani o ovoj problematici, razlog tomu može biti nedostatno znanje, dok se kod studenata FSB i HRSTUD može pretpostaviti da je razlog neinformiranost. Interesantno je da je najprepozna- tija funkcija za studente ŠF bila uloga šuma u zaštiti od erozije, koju je prepoznalo 97\% studenata, dok je uloga šuma u proizvodnji kisika po prepoznatosti tek na petom mjestu (!), a prepoznalo ju je 83,3\% studenata (Tablica 2). Za razliku od njih, uloga šuma u proizvodnji kisika bila je na prvom mjestu po prepoznatosti za studente drugih dvaju fakulteta. Također pokazalo se da postoji statistički značajna razlika u prepoznatosti pojedinih funkcija među fakultetima (Tablica 3), gdje je gotovo uvijek postojala razlika između ispitanika ŠF i ostala dva fakulteta, dok je gotovo nije bilo između ispitanika FSB i HRSTUD. Prema pregledu literature iz uvoda ovoga članka, uloga šuma u turizmu je funkcija koja je najbolje pokrivena znanstvenom literaturom, ali nije bila među pet najprepoznatijih ni na jednom fakultetu. Ipak, studenti ŠF su je značajno više prepoznavali u odnosu na studente drugih dvaju fakulteta (Tablice 2 i 3 ). Kada se uzmu u obzir najslabije prepoznate funkcije, zajedničko je studentima svih triju fakulteta slaba prepoznatost uloge šuma u obrani zemlje i uloge u razvoju lokalne zajednice. Interesantno je i da je za studente ŠF uloga šuma u zaštiti prirode među tri najslabije prepoznate funkcije. Rezultat je pogotovo interesantan u kontekstu sve veće osviještenosti društva o potrebi zaštite prirode, kao i intenzivnoj raspravi o ulozi šumarstva u Natura 2000 mreži zaštićenih područja. Studenti FSB i HRSTUD slabo su povezivali ulogu šuma u zaštiti od bujica s općekorisnim funkcijama šuma, što također smatramo da je zbog neinformiranosti (Tablica 4).

Kada se radi o upoznatosti s pojmom Naknade za korištenje općekorisnih funkcija šuma, preko $90 \%$ ispitanika ŠF izjavilo je da su upoznati, za razliku od ispitanika FSB gdje je takvih samo 5,3\%, dok su svi ispitanici HRSTUD izjavili da nisu upoznati s pojmom (Slika 2). Najvjerojatniji razlog 
za ovakve rezultate je informiranost studenata ŠF o problematici kroz redovnu nastavu. $S$ druge strane, uzimajući u obzir da je Naknada često bila predmet rasprave u dnevnim tiskovinama u sklopu teme o smanjenju parafiskalnih nameta (Barilar i Radusinović, 2013; Marić, 2013; Vukadinović, 2014; Poslovni dnevnik, 2013, 2014, 2015), a u kojoj se gotovo uvijek spominjao „doprinos za šume“, bilo je za očekivati da su i studenti drugih fakulteta barem čuli o tome. Ipak, odgovori na pitanja znanja o Naknadi, poput aktivnosti koje se financiraju iz Naknade (Tablica 4), tko su obveznici plaćanja (Slika 3), te tko raspolaže sredstvima Naknade (Slika 4), pokazali su da studentima svih triju fakulteta nedostaje znanja o ovoj temi, bez obzira na prethodnu informiranost studenata ŠF zbog koje bi trebali biti u prednosti nad studentima ostalih dvaju fakulteta. Studenti triju fakulteta najbolje su prepoznali pošumljavanje te sanaciju i obnovu ugroženih šuma kao aktivnosti koje se financiraju iz sredstava Naknade. Interesantno je da su u puno većem postotku studenti FSB i HRSTUD prepoznali čuvanje šuma, za razliku od studenata ŠF. Uzimajući u obzir prvobitnu namjenu Naknade, a to je da sufinancira gospodarenje šumama na kršu, zanimljivo je da je ta aktivnost među najprepoznatijima jedino studentima ŠF (manje od tri četvrtine ispitanika). $S$ druge strane je prilično neočekivano da studenti ŠF nisu upoznati s činjenicom da se iz sredstava Naknade financira izrada programa gospodarenja privatnim šumama ili izgradnja šumskih prometnica, pogotovo kad se uzme u obzir da su privatne šume i šumarstvo sve češće tema u šumarskom sektoru u Hrvatskoj, posebice od osnutka Šumarske savjetodavne službe 2006. godine do danas.

Istraživanje je pokazalo da su studentima prilična nepoznanica administrativna stajališta Naknade u smislu obveznika plaćanja i institucije zadužene za raspolaganje prikupljenim sredstvima (Slike 3 i 4). Tako je primjerice studentima FSB bilo najlogičnije da Naknadu plaćaju radnici, dok se najviši postotak odgovora studenata HRSTUD odnosio na dobrovoljno plaćanje svih građana. Ministarstvo poljoprivrede čini se najlogičnijim izborom institucije koja bi trebala raspolagati prikupljenim sredstvima Naknade prema iskazanom mišljenju studenata svih triju fakulteta.

Kada se radi o izjavama vezanim za Naknadu (Slike 5-8) pokazalo se da relativno velik udio studenata uopće nema mišljenje o pojednoj temi. Tako primjerice približan udio ispitanika nema mišljenje o namjenskom trošenju i transparetnosti trošenja sredstava, a što smatramo da nije rezultat samo nedostatka informiranosti, već i nedostatak transparentnosti same institucije koja raspolaže sredstvima. Znatno veći udio ispitanika na svim fakultetima imao je mišljenje o ulozi Naknade u unaprjeđenju stanja šuma u RH ili o ukidanju Naknade. Pri tomu je prosječna ocjena slaganja s tvrdnjom da Naknada doprinosi unaprjeđenju bila viša u odnosu na ostale izjave. Zaključujemo da bez obzira na manjak informiranosti i/ili znanja o problematici, studenti ipak imaju pozitivan stav prema Naknadi i ne bi je ukinuli.

Na osnovi rezultata zaključujemo da informiranost donekle utječe na poznavanje problematike općekorisnih funkcija šuma. Tako je gotovo uvijek postojala statistički značajna razlika u odgovorima između studenata ŠF i drugih dvaju fakulteta. Ipak, vjerojatnost je da postoje i neki drugi faktori koji utječu na informiranost i formiranje stava o općekorisnim funkcijama šuma i Naknadi za njih, a koji nisu bili predmet ovog istraživanja. Primjerice, iako pouzdano znamo da su studenti ŠF informirani o općekorisnim funkcijama šuma i Naknadi, odgovori na pitanja znanja nisu uvijek odražavali njihovu prednost u tom smislu u odnosu na studente drugih dvaju fakulteta.

Kako uzorak na kojemu je bilo provedeno istraživanje nije bio reprezentativan, zaključke nije moguće projicirati na opću populaciju, odnosno građanstvo u cjelini. Ipak, zaključujemo da je potrebno više raditi na promociji problematike općekorisnih funkcija šuma, ne samo u znanstvenim i stručnim časopisima, i to na način koji je prilagođen nestručnom građanstvu. Kad se radi o segmentu nestručnog građanstva u koji spadaju obveznici plaćanja, davanje povratne informacije o utrošku sredstava povećalo bi transparentnost (Vuletić et al., 2010 i rezultati ovog istraživanja). Mišljenja smo da bi bolje razumijevanje problematike kroz bolju informiranost građanstva donijelo veću podršku šumarskom sektoru u njihovim nastojanjima da osiguraju općekorisne funkcije šuma. Pogotovo se to odnosi na pojašnjenje vezano za korisnike općekorisnih funkcija šuma, tj. treba li se smatrati korisnikom samo onaj koji je fizički u šumi ili se bavi poslovima vezanim za šume, ili to uključuje sve građane bez obzira gdje se trenutačno nalazili i čime se bave u gospodarskom smislu.

U budućnosti je neophodno nastaviti istraživati razumijevanje i stavove različitih segmenata građanstva o općekorisnim funkcijama šuma i Naknadi, kako bi se razvili i primijenili prikladni instrumenti šumarske politike, a kojima bi cilj bilo veće razumijevanje problematike i pozitivniji stav prema šumarskim aktivnostima u tom smislu.

\section{ZAHVALE}

\section{ACKNOWLEDGEMENTS}

Istraživanje je provodeno u sklopu projekta Značaj i uloga OKFŠ-a u kontekstu EU za potrebe tvrtke Hrvatske šume d.o.o., a koji je financiran iz sredstava Naknade za korištenje općekorisnih funkcija šuma. Ovim putem zahvaljujemo se izv.prof. Stjepanu Posavcu sa Šumarskog fakulteta, prof. dr.sc. Snježani Kereković sa Fakulteta strojarstva i brodogradnje, te izv. prof. Danijelu Labašu sa Hrvatskih studija, koji su nam pomogli u distribuciji anketnih listića studentima. Također, veliko hvala studentima koji su odvojili vrijeme da sudjeluju u ovom istraživanju. 


\section{LITERATURA}

\section{REFERENCES}

- Anon., Pravilnik o uređivanju šuma, NN 52/1994

- Anon., Zakon o šumama, NN 140/2005, 82/06, 80/2010, 25/2012, 68/2012- Odluka i rješenje Ustavnog suda RH broj: U-I-1408/2010 i dr. od 29. svibnja 2012

- Anon., Zakon o šumama, NN 20/1977. Tekst Zakona objavljen 1977. u Šumarskom listu 101(5-7): 229-257

- Anon., Zakon o šumama, NN 52/1990

- Anon., Zakon o šumama, NN 54/1983

- Barilar, S., Radusinović, D., 2013: Ukida se doprinos za šume i još 49 parafiskalnih nameta. Jutarnji list, 28.8.2013. Dostupno na http://www.jutarnji.hr/otkrivamo-koji-ce-se-parafiskalninameti-i-doprinosi-uskoro-ukinuti-/1122645/, pristupljeno 10.1.2016.

- Constanza, R., D’Arge, R., De Groot, R., Farber, S., Grasso, M., Hannon, B., Limburg, K., Naeem, S., O’Neill, R.V., Paruelo, J., Raskin, G.R., Sutton, P., Van der Belt, M., 1997: The value of the world's ecosystem services and natural capital. Nature 387: 253260

- De Koning, F. Aguiñaga, M., Bravo, M., Chiu, M., Lascano, M., Lozada, T., Suarez, L., 2011: Bridging the gap between forest conservation and poverty alleviation: the Ecuadorian Socio Bosque program. Environmental Science \& Policy 14(5): 531-542

- De Vaus, D., 2005: Surveys in social research. 5th edition, Routhledge, 379 str., St Leonards, NSW, Australia

- Delač, D., 2013: Zapisnik 117. redovite sjednice skupštine Hrvatskoga šumarskog društva. Šumarski list 137(5-6): 351-357

- Farley, J., Aquino. A., Daniels, A., Moulaert, A., Lee, D., Krause, A., 2010: Global mechanisms for sustaining and enhancing PES schemes. Ecological Economics 69(11): 2075-2084

- Fisher, B., Kulindwa, K., Mwanyoka, I., Turner, R. K., \& Burgess, N. D., 2010: Common pool resource management and PES: Lessons and constraints for water PES in Tanzania. Ecological Economics 69: 1253-126

- Gómez-Baggethum, E., De Groot, R., Lomas, P.R., Montes, C., 2010: The history of ecosystem services in economic theory and practice: from early notions to markets and payment schemes. Ecological Economics 69: 1209-1218

- Halder, P., Pietarinen, J., Havu-Nuutinen, S., Pöllänen, S., Pelkonen, P., 2016: The Theory of Planned Behavior model and students' intentions to use bioenergy: A cross-cultural perspective. Renewable Energy 89: 627-635

- Horak, S., Marušić, Z., Weber, S., 2001: The aesthetic and recreational value of Croatian coastal forests to the local population. Final Report. Institut za turizam, 3-47, Zagreb

- Ivančević, V., 1983: Šumarstvu na kršu predstoje bolji dani. Šumarski list 107(11-12): 509-524, Zagreb

- IBM Corp., 2011: IBM SPSS Statistics for Windows, Version 20.0. Armonk, NY: IBM Corp.

- Ivančević, V., Piškorić, O., 1986: Obnova šuma na kršu Hrvatske od prošlog stoljeća do danas. Šumarski list 110(7-8): 323347, Zagreb

- Koellner, T., Sell, J., Navarro, G., 2011: Why and how much are firms willing to invest in ecosystem services from tropical for- ests? A comparison of international and Costa Rican firms. Ecological Economics 69: 2127-2139

- Krajter Ostoić, S., Posavec S., Vuletić, D., Stevanov M., 2013: Pregled literature o vrednovanju koristi od urbanih šuma. Radovi Hrvatskog šumarskog instituta 45(2): 161-173, Jastrebarsko

- Krnjak, T., 1977: Novi Zakon o šumama SR Hrvatske i tekst zakona. Šumarski list 101(5-7): 223-228, Zagreb

- Krnjak, T., 1979: Unapređenje gospodarenja šumama i šumskim zemljištima kraškog područja u svjetlu primjene Zakona o šumama u Socijalističkoj Republici Hrvatskoj. Šumarski list 103(1-3): 25-28, Zagreb

- Krpina, V., Španjol, Ž., Jazbec, A., 2014: Uloga šuma i šumarstva u turizmu i zaštiti prirode na području Zadarske županije. Šumarski list 138(5-6): 271-281

- Krznar, A., Lindić, V., Vuletić, D., 2000. Metodologija vrednovanja korisnosti turističko-rekreacijskih usluga šuma. Radovi Šumarskog instituta Jastrebarsko 35(1): 65-82, Jastrebarsko

- Kumar, P., 2005: Market for Ecosystem Services. International Institute for Sustainable Development. Dostupno na www.iisd. org, pristupljeno 19. siječnja 2016.

- Marić, J., 2013: Kojih 14 neporeznih davanja Linić ukida do kraja godine? Novi list, 27.11.2013. Dostupno na http://www. novilist.hr/Vijesti/Gospodarstvo/Kojih-14-neporeznih-davanja-Linic-ukida-do-kraja-godine, pristupljeno 10.1.2016.

- Milas, G., 2009: Istraživačke metode u psihologiji i drugim znanostima. Naklada Slap, 726 str., Jastrebarsko

- Millenium Ecosystem Assessment, 2003: Ecosystems and human well-being. A framework for assessment. Island Press. Dostupno na: http://www.unep.org/maweb/en/Framework.aspx, pristupljeno 7. siječnja 2016.

- Muradian, R., Corbera, E., Pascual, U., Kosoy, N., May, P.H., 2010: Reconciling theory and practice: An alternative conceptual framework for understanding payments for environmental services. Ecological Economics 69: 1202-1208

- Poslovni dnevnik, 2013: Ukida se 25, a smanjuje 27 nameta. Objavljeno 29.12.2013. Dostupno na http://www.poslovni.hr/ hrvatska/ukida-se-25-a-smanjuje-27-nameta-260078, pristupljeno 10.1.2016.

- Poslovni dnevnik, 2014: Smatrate li da Hrvatska ima previše parafiskalnih nameta te za koje smatrate da su suvišni? Objavljeno 1.4.2014. Dostupno na http://www.poslovni.hr/poduzetnik/smatrate-li-da-hrvatska-ima-previse-parafiskalnih-nametate-za-koje-smatrate-da-su-suvisni-267965, pristupljeno 10.1.2016.

- Poslovni dnevnik, 2015: Za 161 parafiskalni namet tvrtke uplatile 5,4 mlrd. Kn. Objavljeno 10.12.2015. Dostupno na http:// www.poslovni.hr/hrvatska/za-161-parafiskalni-namet-tvrtkeuplatile-54-mlrd-kn-305939, pristupljeno 10.1.2016.

- Prager, K., Reed, M., Scott, A., 2012. Encouraging collaboration for the provision of ecosystem services at a landscape scale Rethinking agri-environmental payments. Land Use Policy 29: 244-249

- Prpić, B., 1992: O vrijednosti općekorisnih funkcija šume. Šumarski list 116(6-8): 301-312, Zagreb

- Sabadi, R., Vuletić, D., Gračan, J., 2005: Croatia. U: Merlo M., Croitoru, L., (ur.): Valuing Mediterranean Forests. Toward Total Economic Value. CABI, 249-262, Italy 
- Sommerville, M. M., Jones, J. P.G., Milner-Gulland, E. J., 2009: A revised conceptual framework for payments for environmental services. Ecology and Society 14(2): 34 [online] URL: http:// www.ecologyandsociety.org/vol14/iss2/art34/

- Stevanov, M., Dobšinská, Z., Surový, P., 2015: Assessing surveybased research in forest science: Turning lemons into lemonade? Forest Policy and Economics, in press, doi:10.1016/j.forpol.2015.07.004

- Tarnaj, I., 2012: Opet kroje funkcioniranje šumarstva (OKFŠ). Šumarski list 136(3-4): 189-190, Zagreb

- Tišma, S., Pisarović, A., Farkaš, A., 2002: Ekološko i ekonomsko vrednovanje šuma u Republici Hrvatskoj. Metoda cost-benefit analize. Socijalna ekologija 11(1-2): 115-131, Zagreb

- Tomašević, A., 1979: Na pragu stoljeća rada na pošumljavanju i melioraciji krša. Šumarski list 103(1-3): 11-24Torkar, G., Verlič, A., Vilhar, U., 2014: Importance of forest ecosystem services to secondary school students: a case from the North-West Slovenia. SEEFOR 5(1): 35-43, Zagreb

- Uredništvo Šumarskog lista, 2011: Na kraju 2011. Godine međunarodne godine šuma. Šumarski list 135(11-12): 541-541, Zagreb

- Uredništvo Šumarskog lista, 2013: Šumarstvo sa i bez naknade za općekorisne funkcije šuma. Šumarski list 137(5-6): 277-277, Zagreb

- Vukadinović, N., 2014: Parafiskalni nameti i dalje su ubojice malaksalih poduzetnika. Glas Slavonije, 24.11.2014. Dostupno na http://www.glas-slavonije.hr/253672/1/Parafiskalni-nameti- i-dalje-su-ubojice-malaksalih-poduzetnika, pristupljeno 10.1.2016.

- Vuletić, D., 2002: Metode vrednovanja cjelovitog učinka turističkih irekreacijskih usluga šuma za otok Korčulu kao pilot objekt. Disertacija, Šumarski fakultet Sveučilišta u Zagrebu, str. 337, Zagreb

- Vuletić, D., Vondra, V., Szirovicza, L., Paladinić, E., 2006: Rezultati ispitivanja sklonosti turista za boravak u šumi i odnos prema ekološkim i socijalnim uslugama šuma. Radovi Šumarkog instituta Jastrebarsko 41 (1-2): 83-90, Jastrebarsko

- Vuletić, D., Krajter, S., Mrazek, M., Ćorić, A., 2009: Nedrvni šumski proizvodi i usluge - koristimo li ih dovoljno? Šumarki list 133(3-4): 175-184, Zagreb

- Vuletić, D., Posavec, S., Krajter, S., Paladinić, E., 2010: Payments for Environmental Services (PES) in Croatia - Public and Professional Perception and Needs for Adaptation. SEEFOR 1(2): 61-66, Zagreb

- Vuletić, D., Krajter, S., Vlainić, O., 2011: Pregled stavova lokalnog stanovništva i korisnika o nedrvnim proizvodima i uslugama šuma. Šumarski list 135(13): 222-229, Zagreb

- Wendland, K.J., Honzák, M., Portela, R., Rubinoff, S., Randrianarisoa, J., 2009: Targeting and implementing payments for ecosystem services: Opportunities for bundling biodiversity conservation with carbon and water services in Madagascar. Ecological Economics. 69: 2093-2107

- Zbinden, S., Lee, D.R., 2004: Paying for environmental services: An analysis of participation in Costa Rica's PSA programme. World Development 33(2): 255 - 272

\section{Summary}

Ecosystem services including forest ecosystem services are hot topic globally among scientists and practitioners for decades. In Croatia there is a long tradition of discussing forest ecosystem services in terms of how to systemise them, assess and value, as well as how to secure payment for their provision. However, literature review showed discrepancy between scientific and professional production and importance of this topic for forestry sector in Croatia. This is especially a fact when it comes to research related to citizen perceptions and attitudes and whether they are informed about the topic. Therefore, the purpose of this paper is to analyse the role of information in better understanding of the topic with the assumption that being informed leads to better understanding of the topic. Survey questionnaire was applied on the sample of three student populations of the University of Zagreb - Faculty of Forestry (FoF), Faculty of Mechanical Engineering and Naval Architecture (FMENA) and Centre for Croatian Studies (CCS) (Table 1). The hypothesis was made that respondents from FoF would have better understanding of the topic since they are more informed through their study programme in comparison to respondents from other two faculties. The sample was purposeful and convenient at the same time, and included 247 respondents. Statistical Package for Social Sciences (SPSS) was used for statistical data analysis that included Chi-square and Kruskal-Wallis non-parametric tests beside descriptive statistics. Results showed that respondents from FoF in their own opinion were more informed about the topic of forest ecosystem services and payment for ecosystem services in comparison to respondents from other faculties (Figures 1 and 2). However, questions concerning their actual knowledge on the topic showed that even them had problems with recognising forest ecosystem services and purposes of the payment for forest ecosystem services (Tables 2 and 4). However, there was always statistically significant difference in answers between respondents from FoF and other two faculties (Table 3). When asked about who has the obligation to pay for forest ecosystem services respondents provided various answers, while only $29.2 \%$ of respondents from FoF, 9.9\% of respondents from FMENA and 15.2\% of respondents from CCS provided correct answer to this question (Figure 3). Similarly respondents were asked about the institution responsible for distribution of resources collected as payment for forest ecosystem services. Correct answer was given only by $41.5 \%$ of respondents from FoF, 26.8\% from FMENA and 19.7\% from CCS (Figure 4). Furthermore, respond- 
ents were asked to express their agreement with four statements related to payment for forest ecosystem services in terms of purposeful and transparent money spending, whether it contributes to the better state of forests in Croatia or it should be abolished (Figures 5-9). Results showed that rather high share of respondents does not have opinion, especially respondents from FMENA and CCS. The conclusion is that information has a role in better understanding of the topic of forest ecosystem services, but there are probably other factors that were not included in this research. In future it is important to continue studying understandig and attitudes of various segments of citizens. The purpose of these studies would be to contribute to creation and implementation of proper forest policy instruments that would help in better understanding of the topic and eliciting positive attititude towards forestry activities related to forest ecosystem services by citizens.

KEY WORDS: survey, students, payment for forest ecosystem services, Croatia, forest policy

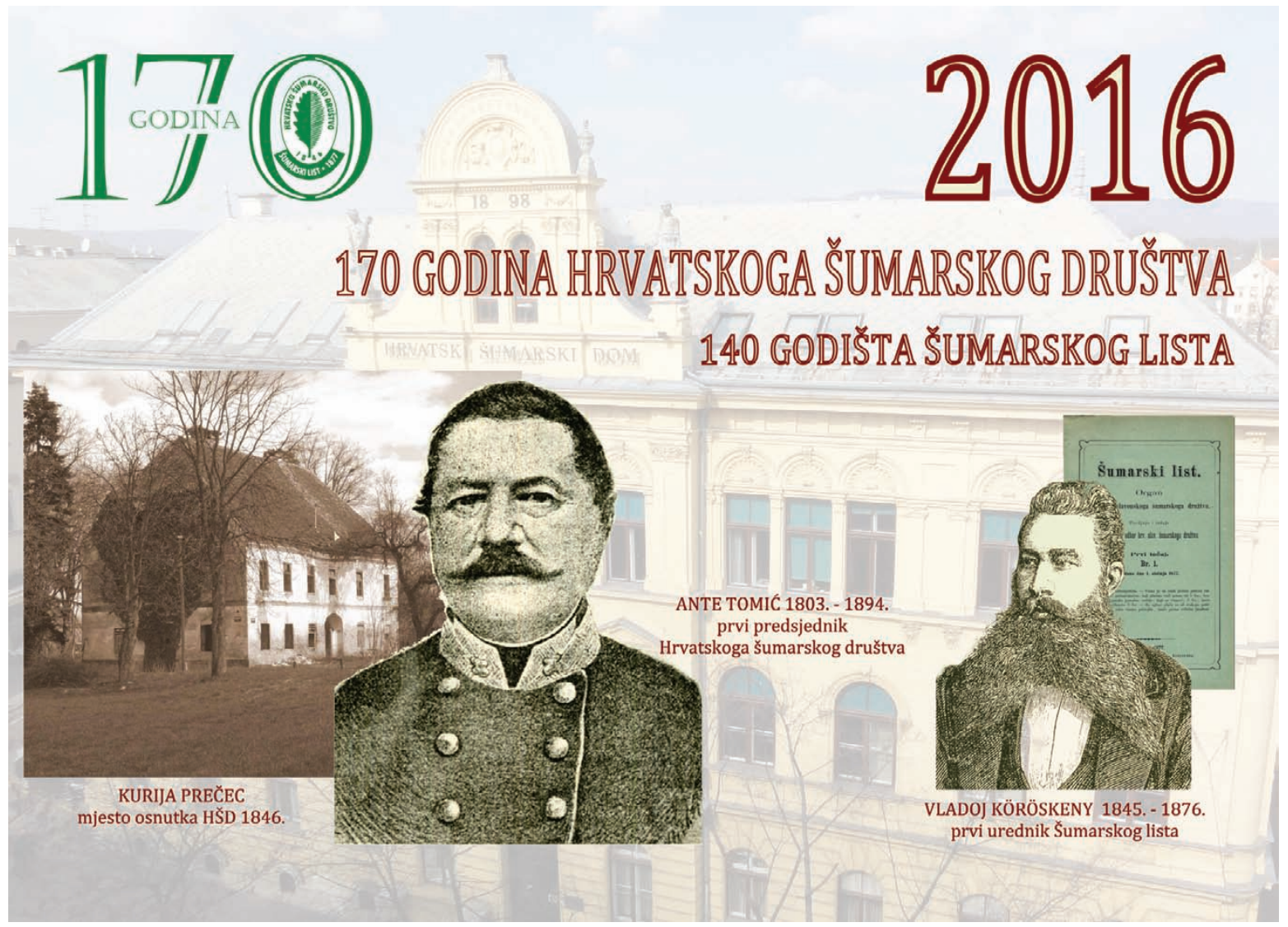

